\title{
A Preliminary Inventory of Hazardous Medical Waste Disposal Systems and their influence on Groundwater Quality in Lusaka
}

\author{
*Nkhuwa D.C.W. ${ }^{1}$, Kafula T. ${ }^{2}$, Ahmed ${ }^{1}$ A.H. \\ ${ }^{I}$ School of Mines, University of Zambia, Lusaka, Zambia \\ ${ }^{2}$ University Teaching Hospital, Private Bag RW 1X, Lusaka, Zambia, e-mail: tkafula@yahoo.com
}

\begin{abstract}
Water forms the basis of life and an essential prerequisite for any socio-economic development and growth. Currently, groundwater has increasingly become a comparatively cheap source of water supply for domestic and other uses in Zambia. However, in Lusaka, the aquifer is vulnerable and fragile because it is shallow and hosted by an open karst system. Since waste management practices have become increasingly inappropriate, such that some of the waste has ended up in karst caverns, there are increased threats of unhindered infiltration of leachate and contaminants to the aquifer. Medical waste constitutes one form of waste, which is inappropriately handled and disposed of in Lusaka. To check on the effects of such practices, the research team undertook mapping of healthcare centres in Lusaka, took an inventory of the types of medical wastes produced at each centre, and their methods of disposal. Seven water points located near these possible sources of pollution were sampled in Chawama, Kanyama, Matero Main, Matero Reference, Kalingalinga, Chipata and George clinics and tested for $\mathrm{pH}$, conductivity, total dissolved solids, total coliforms, faecal coliforms and chemical oxygen demand (COD) as $\mathrm{O}_{2}$. Results of these tests revealed that only two water points met the WHO guidelines for drinking water.
\end{abstract}

\footnotetext{
*Corresponding Author

Nkhuwa D.C.W

School of Mines, University of Zambia,

P O Box 32379, Lusaka, Zambia, e-

mail: dcwnkhuwa@yahoo.com or

dcnkhuwa@unza.zm
}

\section{INTRODUCTION}

Lusaka, the capital city of the Republic of Zambia, is underlain by rock that possesses a karst hydrosystem. And like any other rock with such a hydrosystem, it is very vulnerable to pollution due to its complex and unique characteristics, such as high heterogeneity in groundwater flow that has been created and structured by differential dissolution of the rock (Figure 1). This, in turn, has created large voids that have the potential to offer comparatively high groundwater flow velocities and a strong connection with surface water systems. These characteristics make the Lusaka (and any other) karst hydrosystem very different from other normal aquifers and thus, make this hydrosystem very sensitive to various land use practices, such as onsite sanitation, and handling and disposal of medical waste, which may pose great risk of groundwater pollution in Lusaka.

This research was conducted with a view to assessing the different methods of medical waste disposal used in Lusaka, and the possible pollution hazards, which such practices would pose to groundwater resources in the fragile Lusaka environment. This assessment was undertaken with a view to setting-up an early-warning system for groundwater pollution episodes in the Lusaka aquifer. The outcome of this assessment was intended to be an input into the formulation of recommendations for the protection of the Lusaka aquifer. Protection of the Lusaka aquifer would, in turn, assist in curtailing the city's groundwater resources from being possible pathways for diseasecausing pathogens to the population that consumes such water.

\section{Keywords}

karst terrain, medical waste, groundwater, pollution, public health 


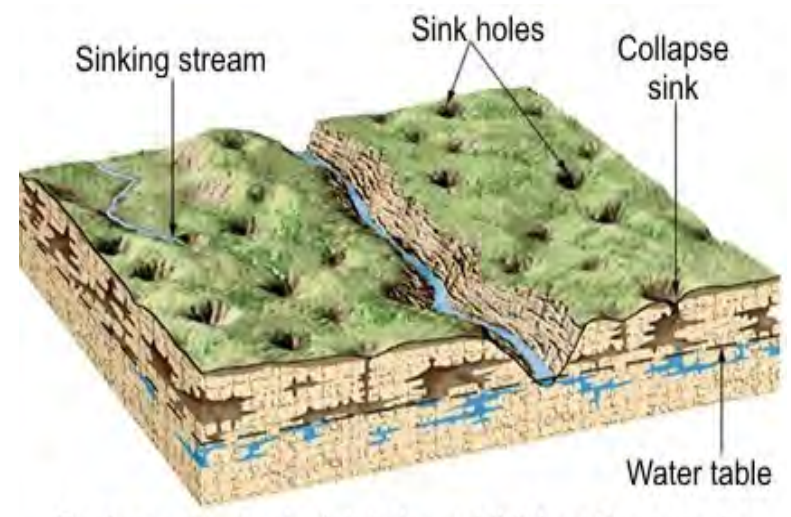

Regions with mank sink holes exhibit karst topography

Figure 1. Typical karst topography in a marble terrain

\section{LOCATION, GEOMORPHOLOGY AND DRAINAGE}

The city of Lusaka is situated at about $15^{\circ} \mathrm{S}$ and $28^{\circ}$ $\mathrm{E}$ (Figure 2). It is located on a plateau of midTertiary (Miocene) age. The plateau stands at an elevation of 1,300 metres above sea level (a.s.1). Both the plateau's topography and morphology have been greatly influenced by the underlying geology. The terrain is characterised by a conspicuous scarcity and/or complete lack of surface drainage particularly in its central part. This indicates that most of the rainwater on the plateau drains into fissures, and/or infiltrates through soil that forms the overburden, to join the underground water system. Only surface water in excess of infiltration is drained into minor seasonal streams.

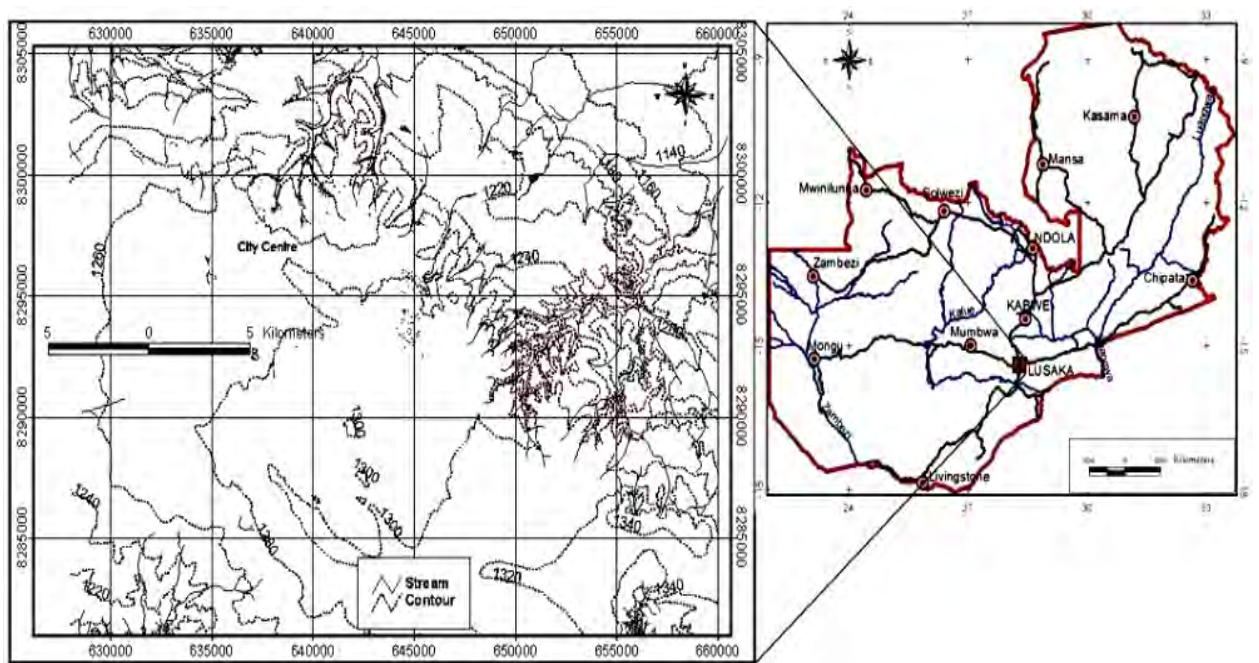

Figure 2. The Lusaka topography and city's location in Zambia (Adapted from [1])

\section{HYDROGEOLOGY}

Data from borehole logs from different parts of the Lusaka plateau indicate that the marbles extend to depths in excess of 100 metres below ground surface. However, the rock shows variations a decrease in fracturing intensities with depth. Although some of the solution features do not show any evidence of occurrence on surface, they extend to great depths in the subsurface. Some of them were intersected at depths in excess of $80 \mathrm{~m}$. Their occurrence and orientation have greatly dictated the general course of groundwater flow in the Lusaka aquifer ${ }^{1}$.

From borehole logs and other geologic data, it is evident that there is one major unconfined aquifer underlying the city of Lusaka. However, in some places, repeated NE SW over-thrusting appears to have caused the older and less permeable schists to overlie the marbles, thereby creating semi-confining conditions. The aquifer is generally characterized by shallow water tables, a thin cover of coarse soils with low clay contents, and a flat topography, which all facilitate increased recharge to the aquifer. General groundwater flow direction follows the general strike of the lithology although there is also some influence from the plateau's topography (Figure 3). 


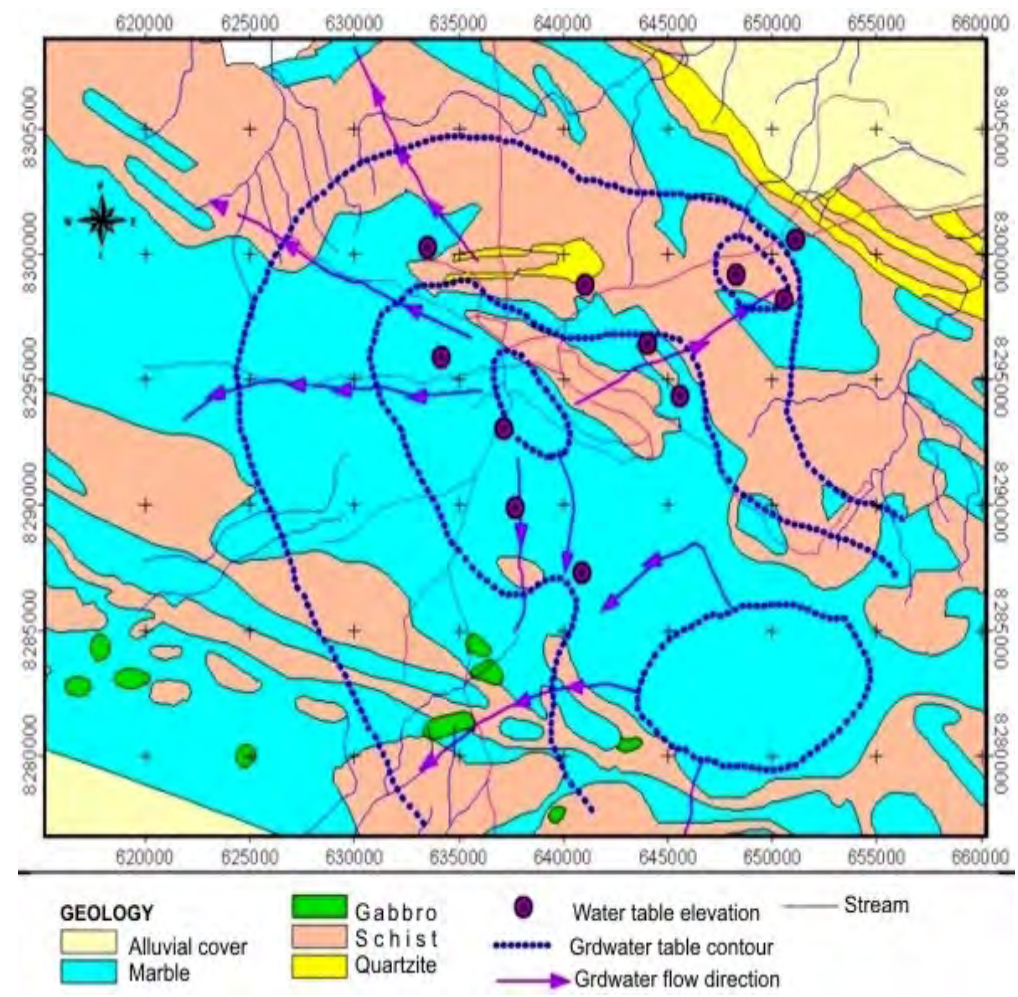

Figure 3. Hydrogeologic map of the Lusaka area, showing flow direction (Source: [1])

In addition, available borehole records also indicate an apparent relationship between water strikes and large scale fracturing/faulting/shearing. While fractures may have enhanced water transmission capabilities of the Lusaka marbles, their presence may also have had the consequence of facilitating unattenuated flow of surface water into the aquifer, thereby making it vulnerability to pollution.

\section{SCOPE OF THE RESEARCH}

The research involved mapping of all the public healthcare centres in Lusaka, which constitute some of the potential sources of pollution for the Lusaka aquifer. Because of limitations imposed by funding levels for this research, private-operated healthcare centres were not mapped. Establishment of the level of pollution in the aquifer arising from medical waste disposal practices involved collection of baseline data on:

a) Location by their X-Y coordinates using a Global Positioning System(GPS) of:

- Solid and medical waste disposal sites and type(s) of wastes disposed in these facilities.
- Existing water sources/points in the vicinity of the above facilities.

b) Water quality testing and data analyses.

\section{LITERATURE REVIEW}

The disposal of medical waste poses a major challenge, not only in Lusaka and Zambia alone, but in many other countries of the world. A Hospital Waste Fact Sheet ${ }^{2}$, for instance, states that in recent years, medical waste disposal has posed even more difficulties with the appearance of disposable needles, syringes, and other similar items. In Pakistan, for instance, around 250,000 tonnes of medical waste are reported to be produced from healthcare facilities in the country every year. Further, the same Hospital Fact Sheet reports that Pakistan has had no proper measures for the management of medical waste, and that disposable syringes and needles are disposed of in dustbins or other similar receptacles because these are the practices that have been deemed safe, inexpensive, and easy solutions to dispose of such potentially 
dangerous items. Consequently, a common practice of reuse of disposable syringes picked from medical waste dumps has been reported. Such inadequate and inappropriate methods of hazardous/toxic solid waste management practices may:

a) Spread contagious diseases like Hepatitis A \& B, typhoid, boils and AIDS.

b) Create challenges for groundwater quality as may be the case in the Lusaka aquifer, where the nature of the ground on which such activities occur have the potential to promote unhindered percolation of contaminants to the groundwater store.

Studies by, among others, ${ }^{1,3,4,5,6}$ in different parts of the city have all revealed widespread chemical and microbiological pollution resulting from various such land use practices. Among the consequences of consuming such water have been the endemic outbreaks of acute diarrhoeal diseases, such as cholera and dysentery.

\section{METHODOLOGY}

a) Desk study synthesised existing geological, hydrogeological and water quality data of the study areas and its integration into a Geographical Information System (GIS).

b) Reconnaissance field visits served to inform sisters-in-charge of health centres and communities of the proposed study. Information on the type and number of water sources available was recorded for use in the sampling design.

c) Detailed fieldwork which involved:

- Mapping of healthcare centres and water points by their X-Y coordinates using a handheld Global Positioning System (GPS)

- Interviews with Environmental Health Technologists (EHTs) regarding the different medical waste treatment/disposal methods and facilities used by their healthcare centres.

- Collection of water samples from boreholes for hydrogeochemical and bacteriological analyses. A GPS was used to record the location of each sample point by its $\mathrm{X}-\mathrm{Y}$ coordinates.

\section{A N INVENTORY OF LUSAKA HEALTHCARE CENTRES' MEDICAL WASTES}

This activity involved mapping of healthcare centres, medical waste treatment/disposal facilities and water points by their X-Y coordinates using a personal hand-held Garmin e-Trex Venture Global Positioning System (GPS). This mapping revealed that waste is generated by a wide variety of healthcare activities in Lusaka, for instance, immunisations, diagnostic procedures, medical treatments and laboratory tests. These activities generated different forms of waste comprising:

- Infectious waste which comprises material containing pathogens (bacteria, viruses, parasites or fungi) in sufficient concentrations/quantities that, if exposed, can cause diseases in susceptible hosts. This includes waste from infectious agents and infected patients, wastes contaminated with blood and its derivatives, contaminated materials (swabs, bandages) and equipment (disposable medical devices).

- Pathological waste consists of tissues, organs, body parts, human flesh, foetuses, blood and body fluids. Pathological and infectious wastes represent the majority of the hazardous waste from healthcare activities.

- Sharps consist of syringes, disposable needles, saws, blades, broken glasses, nails or any other item that could cause a cut.

- Pharmaceutical waste consists of expired, unused and no longer required drugs and chemicals that are returned from wards.

- Radioactive waste comprises solids, liquids and gaseous waste contaminated with radioactive substances used in diagnosis and treatment of diseases like cancer.

- Other waste includes waste from the offices, kitchens, rooms, including bed linen, utensils, paper, etc.

Results of mapped points by their X-Y coordinates were entered in excel spreadsheets and stored, integrated, analysed and displayed in the Geographic Information System(GIS). 


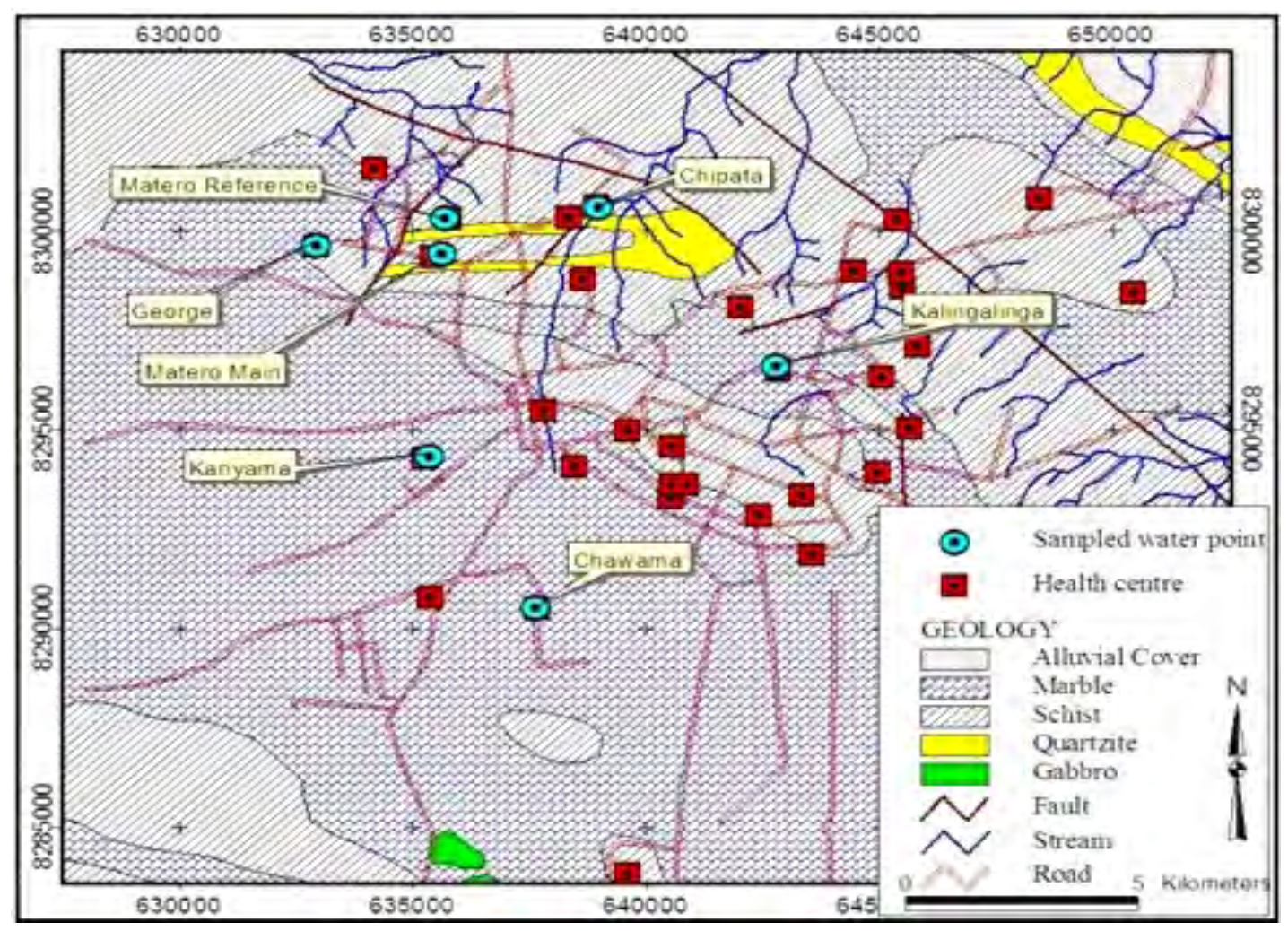

Figure 4. A plot of the mapped healthcare centres and the seven locations, where water samples were collected

\section{MEDICAL WASTE DISPOSAL SYSTEMS AT MOST OF LUSAKA'S HEALTHCARE CENTRES}

Refuse pits, placenta pits, and incinerators have provided the most common methods of handling, treating and disposing of waste by healthcare centres in Lusaka as follows:

a) Refuse pits used to dispose of papers, plastics and empty plastic bottles, kitchen waste and food remains. However, there have been instances, when sharps and other incineratable wastes have sometimes ended up in refuse pits (Figure 5). Such a practice poses the obvious danger of re-use of such waste and the potential for the spread of infectious diseases.

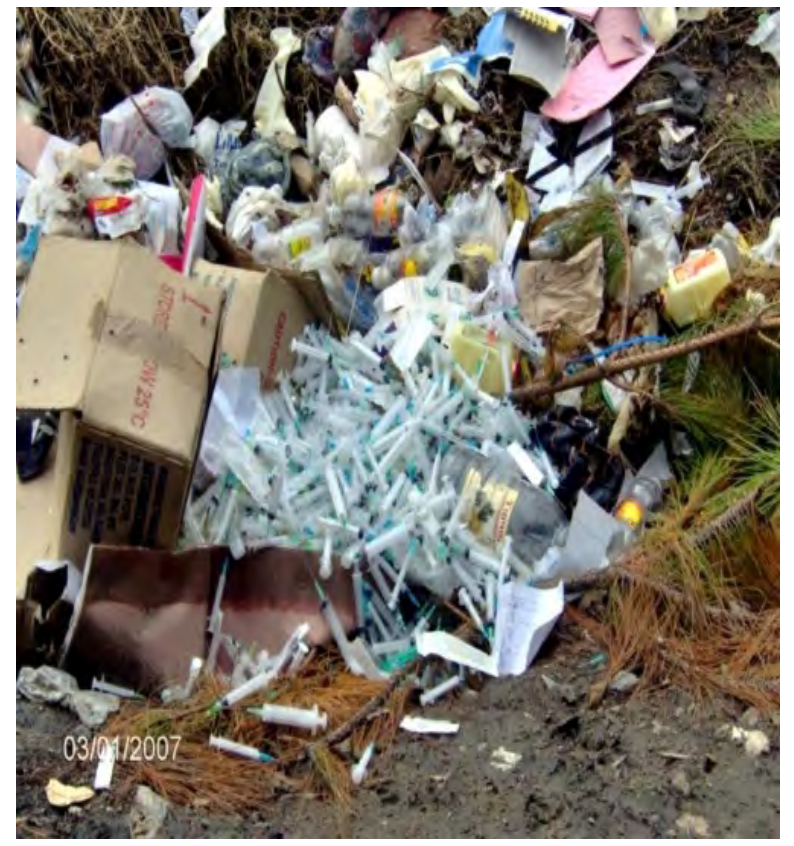

Figure 5. Disposal of sharps at an open dump 
b) Placenta pits used to dispose of placentas. In order to create more space in these pits, digesters, such as sulphuric acid, have been used. Since most of these pits are not lined, there is the potential of blood from these placentas seeping into the ground and with high risk of percolation to the groundwater store.

c) Incinerators these still constitute the disposal method of choice for expired drugs, sharps, sputum bottles, and soiled cotton swabs. Incinerators cater for waste of heterogeneous chemical composition, whose combustion characteristics are determined largely by where it is generated. Therefore, such waste requires to be burned at very high temperatures. However, being in a country that is stressed by resources, use of incinerators that operate mainly on expensive fuel has not been very efficient. Further, although most of the medical wastes deserve incineration, most of the health centres' incinerators were dysfunctional at the time of this research. Consequently, medical wastes most of it untreated ended up in open dumps, while ash remains found application as manure for growing vegetables. Another challenge posed by the use of incinerators arises mainly from the smoke that bellows out of their chimneys (Figure 6). Because of the height of the chimneys, smoke ends up enveloping residential areas that are located on the downwind side of the chimneys, thereby posing different forms of nuisances to the residents.

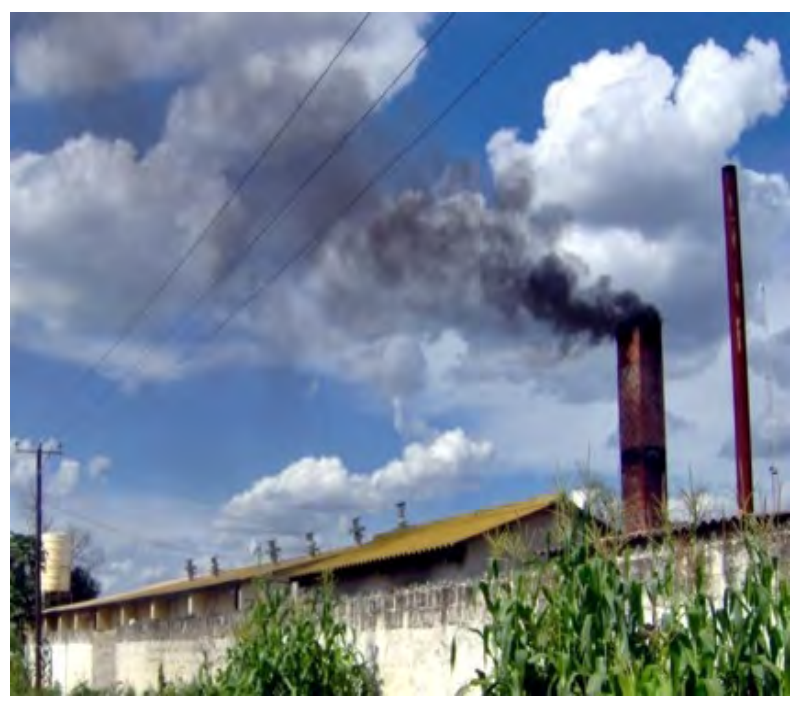

Figure 6. Incinerator chimney bellowing out smoke at a clinic in one residential townships
Although inappropriate disposal of waste has gone unabated in most healthcare centres of Lusaka, George clinic has chosen to be an exception by containing incinerator remains in lined underground excavations (Figure 7).

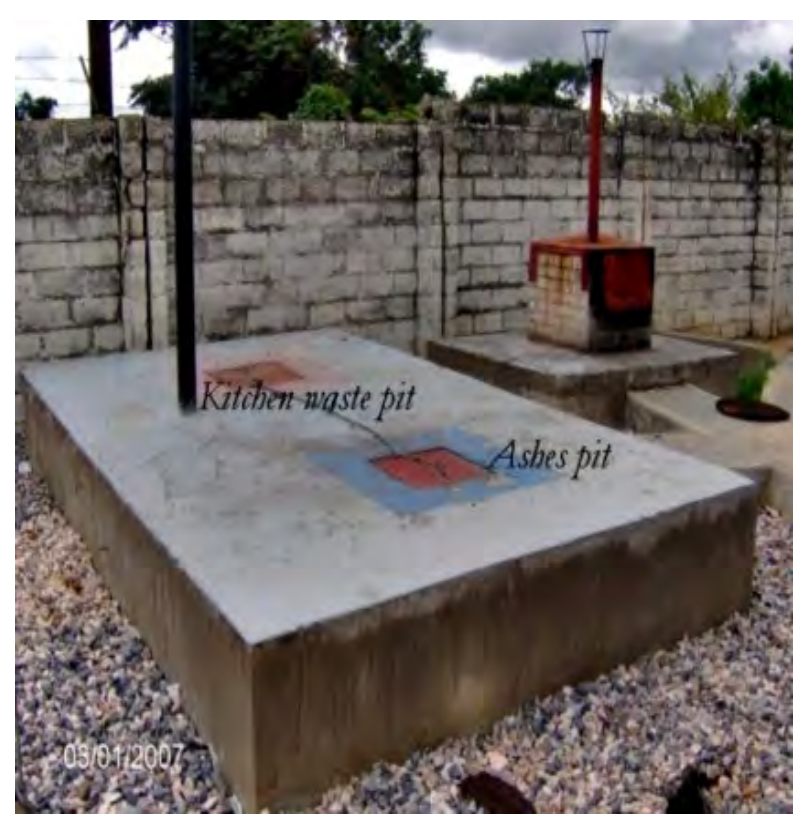

Figure 7. Container for incinerator remains at George clinic

\section{WATER SAMPLING CAMPAIGNS}

In most parts of the city, the water table rises quite close to the ground surface during the wet season. This means that human activities as described above have strong implications on the quality of groundwater as occasional surface flooding has sometimes brought these potential sources of pollution into direct contact with groundwater, posing threats of groundwater pollution. To assess the level of pollution arising from such human activities, water samples were collected from boreholes and GPS coordinates were taken to record the location of each sample. The samples were analysed for (i) $\mathrm{pH}$, (ii) conductivity, (iii) Chemical oxygen demand (COD as O2), (iv) total coliforms, and (v) faecal coliforms. Owing to very low levels of funding for the research, only seven pilot water points were sampled. 
The analyses were done at the Environmental Engineering Laboratory (EEL) in the School of Engineering at the University of Zambia. Methods of analyses used are indicated in brackets against each parameter $\mathrm{pH}$ and Conductivity (Electronic), Chemical Oxygen Demand as $\mathrm{O}_{2}$ (Dichromate Spectrophotometer), Total and Faecal Coliforms (Membrane Filtration).

\section{RESULTS}

Since water levels rise near to the ground surface in most parts of the city during the wet season, human activities described above have had strong implications on the quality of groundwater in the Lusaka aquifer. Occasional surface flooding in the city has sometimes brought these potential sources of pollution into direct contact with groundwater.

\section{Bacteriological quality}

The presence of faecal coliforms in drinking water offers the most common bacterial indicator for recent faecal pollution from humans or animals. The principle concern of the presence of faecal coliforms in groundwater is the health hazard they pose to humans, especially if their presence is in excess of stipulated WHO Guidelines (Table 1). From this Table, except for Matero Reference, Chipata and George clinics, water quality for the rest of water points is impaired bacteriologically.Table 1. A summary of results for boreholes from some healthcare centres in Lusaka
Water samples from George and Chipata clinics have conspicuous absence of faecal coliforms. This may be attributed to the following:

a) The source of water to the George clinic is the JICA boreholes that are drilled on the outskirts of the settlement. The water is conveyed to the tanks that are erected within George compound, chlorinated, and conveyed to consumption points, including George clinic. One tank actually stands within the George clinic grounds. There is one such tank at George clinic (Figure 8).

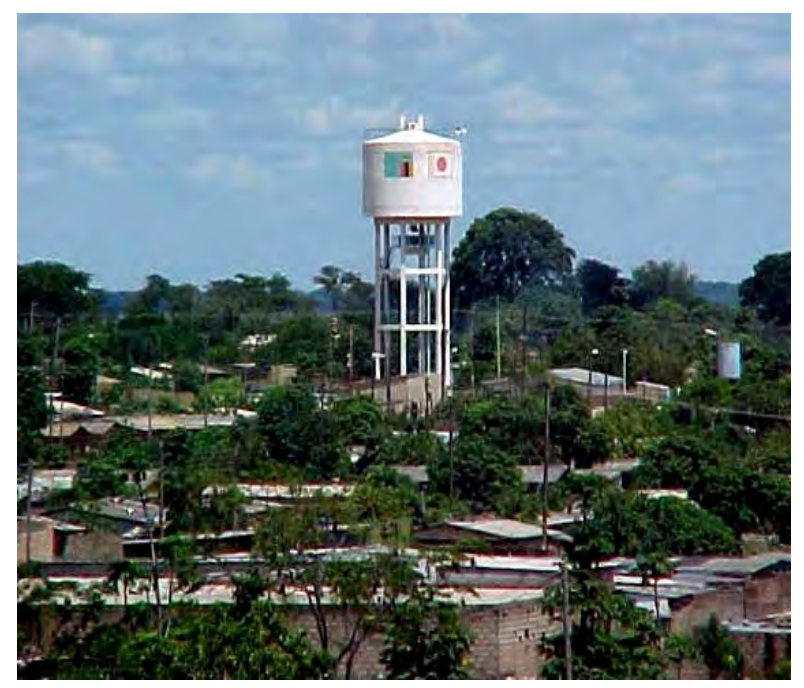

Figure 8. One of the tanks used to distribute water in George compound.

\begin{tabular}{lcccccc} 
Health Centre & $\mathbf{p H}$ & $\begin{array}{c}\text { Conductivity } \\
(\mu \mathrm{S} / \mathrm{cm})\end{array}$ & $\begin{array}{c}\mathbf{T D S}^{*} \\
\left(\mathrm{mg} \mathrm{l}^{-1}\right)\end{array}$ & $\begin{array}{c}\text { Total Coliforms } \\
(\text { counts/100 ml })\end{array}$ & $\begin{array}{c}\text { Faecal Coliforms } \\
(\text { counts/100 ml })\end{array}$ & $\begin{array}{c}\text { COD, as } \mathbf{O}_{2} \\
(\mathrm{mg} / \mathrm{l})\end{array}$ \\
\hline Kalingalinga & 7.6 & 506 & 339 & $\mathbf{5 8}$ & $\mathbf{4 5}$ & 54 \\
Chawama & 7.2 & $\mathbf{1 0 6 0}$ & $\mathbf{7 1 0}$ & 8 & $\mathbf{6}$ & 64 \\
Kanyama & 7.2 & 755 & 506 & $\mathbf{1 7}$ & $\mathbf{7}$ & 45 \\
Matero Main & 7.3 & 621 & 416 & $\mathbf{4 2}$ & $\mathbf{3 7}$ & 54 \\
Matero Reference & 6.7 & 401 & 269 & $\mathbf{1 8}$ & 0 & 48 \\
Chipata & 7 & 795 & 533 & 0 & 0 & 48 \\
George & 7.5 & 548 & 367 & 0 & 0 & 51 \\
WHO Guidelines & $6.5-8.5$ & 1000 & 670 & 10 & 0 & - \\
\hline
\end{tabular}

*TDS $=$ Total dissolved solids, whose value was calculated by multiplying conductivity by a factor of 0.67

Bold values indicate those above the WHO Guidelines 
b) The Chipata clinic borehole is situated away from the main area of human activities (Figure 9).

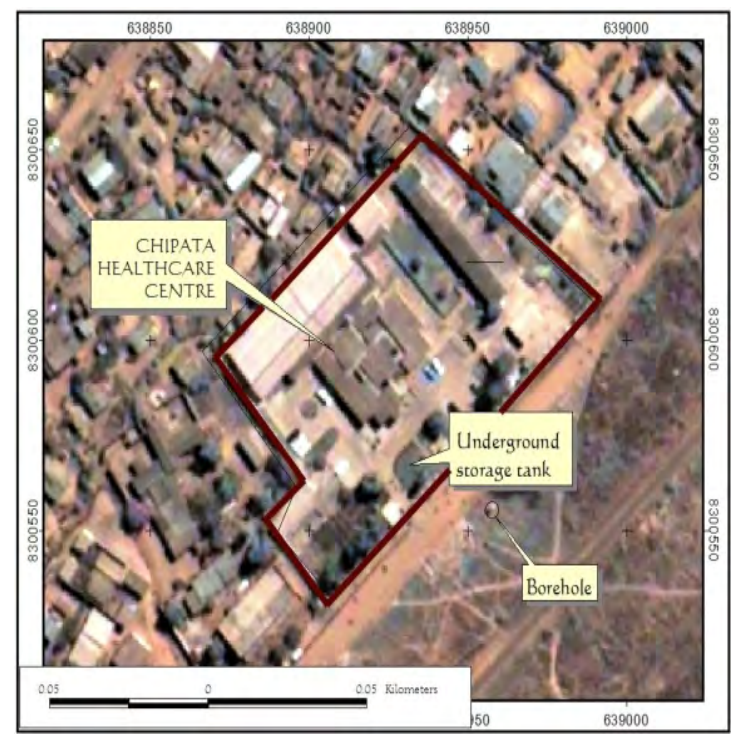

Figure 9. Location of Chipata healthcare centre and the water supply borehole and distribution underground tank.

\section{Conductivity and Total Dissolved Solids (TDS)}

Conductivity gives an indication of the water's ability to conduct an electric current. Thus, it is sensitive to variations in the amount of dissolved solids, mostly mineral salts, and is related to the concentrations of total dissolved solids and major ions.

Although conductivity and TDS values obtained during this research lie within what would generally be termed freshwater ranges, the anomalous values for the Chawama and Chipata boreholes (Table 3) are indicative of elevated concentrations of salts such as nitrate, sulphate and chloride. Since the distribution does not show any trend among the sampled locations, the elevated values may be attributed to local influences at each healthcare centre.

In spite of conductivity not having any known health effects, it raises concern if the high levels are due to nitrates, which have been known to have health effects. In addition, high conductivity/TDS affects the taste and freshness of the water.

\section{Chemical Oxygen Demand (COD)}

Chemical Oxygen Demand (COD), measured as $\mathrm{O}_{2}$, is a quantitative measure of the amount of oxygen required to oxidize all organic components in a sample of wastewater, both non-biodegradable and biodegradable. It is used as a rapid measure of organic pollutants in water.

Although WHO has no Guideline value for COD, 7 recommend concentrations of $\mathrm{COD}$ in surface waters in the range of $20 \mathrm{mg} \mathrm{l}^{-1} \mathrm{O}_{2}$, or less in unpolluted waters. On this basis, COD concentrations obtained from all samples in the study areas of between $45 \mathrm{mg} \mathrm{l}^{-1}$ and $64 \mathrm{mg} \mathrm{l}^{-1} \mathrm{O}_{2}$ (Table 4) may be indicative of polluted water, although this does not differentiate between the organic and inorganic compounds present in the water. The Chawama borehole has elevated conductivity and COD, which may be attributed to waste disposal facilities, which are located in very close proximity to the borehole.

\section{DISCUSSION}

Further, from results of physical-chemical and bacteriological parameters of water samples from healthcare centres, all samples were impaired with respect to chemical oxygen demand (COD) as $\mathrm{O}_{2}$. In addition, except for George Clinic, which is supplied from centrally treated water from JICA tanks, most of the water points at healthcare centres were bacteriologically impaired. However, it is worth of note that it was difficult to separate bacteriological pollution arising from activities at healthcare centres from those that may be caused by poor sewage management in each of the settlements. Thus, it is possible that impairment of groundwater quality in the affected areas may also be related to landfills, poor sewage management (pit latrines and septic tanks), and surface pollution percolating and directly recharging shallow aquifers during the rainy season.

Although results are from only seven randomly selected sample points and may not be considered to be representative enough to indicate aquifer-wide influence of healthcare centres on groundwater quality, they all indicate local groundwater quality 
impairment with regard to most of the selected parameters. Thus, detailed and aquifer-wide groundwater sampling and monitoring on a regular basis, and a selection of appropriate indicatorparameters from different forms of medical wastes, is imperative if the true extent of the impact of healthcare activities in Lusaka are to be measured.

\section{CONCLUSION}

The principal outcome of this study shows that only two out of seven boreholes tested complied with the WHO guidelines. Because of the limitation in the current sampling coverage, it is imperative that more water sampling activities involving a much bigger network be instituted and maintained in order to establish the extent of the pollution problem arising from current methods of medical waste disposal systems. Since human activities are on the increase in Lusaka, challenges of healthcare waste management and levels of water quality impairment in the city are also likely to worsen.

In order to check current medical waste disposal practices, it is imperative that the Ministry of Health (through the District Health Management Team (DHMT)), Environmental Council of Zambia (ECZ), the Drugs and Poisons Control Board (DPCB) work in unison to enforce appropriate pieces of legislation (such as the Environmental Protection, Prevention and Control Act (EPPCA), the Drugs and Poisons Control Board Act), and to ensure that the Zambia Infection Prevention Guidelines are disseminated and implemented as a matter of urgency. After all, waste management is said to be a process NOT a technology it requires a change of thinking (Anonymous).

Finally, this research wishes to recommend that best practices with regard to handling and disposing of incinerator ashes as observed at the George clinic must be replicated in other healthcare centres in Lusaka and elsewhere throughout the country. A summation of these activities is likely to constitute a good starting point to ensuring a city with a safe and protected natural environment, in which people may live a healthy and productive life.

\section{RECOMMENDATIONS}

In order to determine the magnitude and severity of the medical waste disposal challenges in Lusaka, it is recommended that the Ministry of Health (through the DHMT), the ECZ and the DPCB provide funding for a detailed city-wide follow-up study of waste disposal practices at all the healthcare centres in the city.

\section{GLOSSARY OF SOME TERMS USED IN THE TEXT}

Aquifer is an underground layer of water-bearing geologic materials from which groundwater can be usefully extracted using a borehole.

Fault is a planar fracture in rock in which the rock on one side of the fracture has moved with respect to the rock on the other side.

Global Positioning System (GPS) is an electronic system using a network of satellites to indicate on a computerized receiver the position of a person, object, vehicle, ship, etc. on the land surface.

Karst is an area of irregular limestone in which erosion has produced fissures, sinkholes, underground streams, and caverns (as shown in Figure 1 in the text).

Rock fracture is any local separation or discontinuity plane in a geologic formation that divides the rock into two or more pieces. Fractures are commonly caused by stress exceeding the rock strength.

\section{ACKNOWLEDGEMENTS}

The team would like to thank the Government of the Republic of Zambia through the University of Zambia for the research funds; the Lusaka District Health Management Team and the Environmental Council of Zambia (ECZ) for the logistical support; all sisters-in-charge and their EHTs at participating Clinics for their co-operation during the team's visitations. 


\section{REFERENCES}

1. Nkhuwa, D.C.W. Hydrogeological and Engineering Geological problems of urban development over karstified marble in Lusaka, Zambia. Mit. Ing. u. Hydrogeol., Heft 63, Becker Kuns Druck + Verlag GmbH, Aachen, 1996, pp251.

2. http://ww.wwfpak.org/factsheets hwf.php

3. Von Hoyer, M., Köhler, G. \& Schmidt, G. Groundwater and Management Studies for Lusaka Water Supply. Part 1 Groundwater Study, Hanover, 1978.

4. Nkhuwa, D.C.W. Management of groundwater resources in Lusaka, Zambia, and expectations for the future. In: Sililo et al. (Eds.), Groundwater: Past Achievements and Future Challenges, Balkema Rotterdam, 2000, pp993998, ISBN 90-5809-159-7.

5. Nkhuwa, D.C.W. Groundwater quality in the John Laing and Misisi areas of Lusaka. In Xu, Y. \& Usher, B. (Eds.); Groundwater Pollution in Africa, 2006, pp253 263, Taylor \& Francis/ Balkema, Rotterdam, ISBN 10:0-415-41167-X.

6. Nyambe, I.A. and Maseka, D. Groundwater pollution, land use and environmental impacts on Lusaka aquifer. In: Sililo et al. (Eds.), Groundwater: Past Achievements and Future Challenges, Balkema Rotterdam, 2000, pp803808, ISBN 90-5809-159-7.

7. Chapman, D. and Kimstach, V. Selection of water quality variables. In Chapman, D. (Ed.): Water quality Assessments A guide to the use of biota, sediments and water in environmental monitoring. E \& FN Spon, London, Glasgow, Weinheim, New York, Tokyo, Melbourne, Madras; Second Edition, 1996, p626. 